\title{
Blood perfusion of teat tissue in dairy cows: Changes associated with pre-milking stimulation and machine milking
}

\author{
M. Wieland, ${ }^{1 *}{ }^{1 *}$ S. Shirky, ${ }^{2}$ G. Gioia, ${ }^{1}$ A. Sipka, ${ }^{1} \oplus$ P. D. Virkler, ${ }^{1} \oplus$ D. V. Nydam, ${ }^{1} \oplus$ N. Älveby, ${ }^{3} \odot$ \\ and I. R. Porter ${ }^{4}$ (1) \\ ${ }^{1}$ Department of Population Medicine and Diagnostic Sciences, College of Veterinary Medicine, Cornell University, Ithaca, NY 14853 \\ ${ }^{2}$ Department of Animal Science, College of Veterinary Medicine, Cornell University, Ithaca, NY 14853 \\ ${ }^{3}$ DeLaval International AB, Tumba, 14741, Sweden \\ ${ }^{4}$ Department of Clinical Science, College of Veterinary Medicine, Cornell University, Ithaca, NY 14853
}

\section{ABSTRACT}

Mechanical forces during machine milking of dairy cows evoke circulatory impairment of the teat tissue that may affect the teats' defense mechanisms against mastitis pathogens. Ample research describes dimensional changes of different teat traits after machine milking, whereas reports that describe changes in blood circulation of dairy cows' teats are limited. Therefore, the objectives of this study were to (1) describe changes in teat blood circulation that occur after pre-milking teat stimulation and machine milking and (2) study the effect of 2 different milking liners on machine milkinginduced changes in teat blood flow. In a randomized trial, Holstein dairy cows were stratified by parity, stage of lactation, and average daily milk yield during the previous week, and allocated to 1 of 2 treatment groups. Treatment consisted of 1 milking observation with either a round or multisided concave milking liner. Teat scans were taken of the left front and the right hind teats using power Doppler ultrasonography. Imaging occurred before pre-milking udder preparation (T1), after completion of pre-milking udder preparation but before milking-unit attachment (T2), and immediately after unit detachment (T3). Perfusion intensity measurements from teat scans were performed with a commercially available software program. Data from 109 cows were analyzed. A general linear mixed model showed differences in perfusion intensity between time points. Least squares means (95\% confidence intervals) for T1, $\mathrm{T} 2$, and $\mathrm{T} 3$, respectively, were $0.035 \%(0.026-0.047)$, $0.124 \%(0.093-0.164)$, and $0.095 \%$ (0.073-0.124). Conversely, no statistically significant differences between treatment groups were observed. We conclude that teat blood circulation is subjected to several influences,

Received January 18, 2020.

Accepted March 2, 2020.

*Corresponding author: mjw248@cornell.edu including inherent circulatory regulation mechanisms, as well as extrinsic factors such as machine milking. Future research is warranted to decipher the magnitude of their influence and to further our understanding of how these changes relate to the susceptibility to intramammary infection and milking performance.

Key words: angiography, bovine, congestion, edema, teat-end shape

\section{INTRODUCTION}

Vacuum-induced forces applied during machine milking create stress to the teat, which can evoke mechanical and circulatory impairment of its tissue (Hamann et al., 1994b). These machine milking-induced alterations are differentiated into long-, medium-, and short-term teat tissue changes (Mein et al., 2001). Long-term changes are the adaptation of the teat tissue to machine milking over several weeks and are classified into changes of teat-end callosity thickness and roughness (Neijenhuis et al., 2000). Increased teat-end callosity thickness and roughness affect teat canal closure, enhance lodging of pathogenic bacteria, and consequently increase the risk of new intramammary infection (Neijenhuis et al., 2001a). Medium-term changes are defined as tissue changes that occur after a few days or weeks and comprise petechial or larger hemorrhaging of the teat skin (Mein et al., 2001). Short-term changes refer to teat tissue responses to a single milking and are differentiated into congestion and edema (Hamann and Mein, 1990). Because sufficient blood circulation in the teat tissue is paramount for the teats' defense mechanisms against mastitis pathogens (Hamann et al., 1994a), these alterations of the teats' circulatory system have been associated with increased susceptibility to new intramammary infection (Neijenhuis et al., 2001b; Paulrud et al., 2005).

Ample research has described the assessment of dimensional changes for different teat traits to quantify the magnitude of short-term tissue changes that occur 
during machine milking (Hamann and Mein, 1990; Neijenhuis et al., 2001b; Zwertvaegher et al., 2013; Guarín and Ruegg, 2016). Conversely, knowledge about changes in teat blood circulation as induced by machine milking is scarce. Limited information describing measurements of the blood flow in the teat skin with laser Doppler flowmetry dates back almost 3 decades (Persson, 1991; Hamann et al., 1994a). Other researchers used different techniques of measuring teat skin temperature to indirectly determine blood circulation (Eichel, 1992; Ordolff, 2000; Paulrud et al., 2005; Barkova et al., 2019; Tangorra et al., 2019).

Doppler ultrasonography (USG) is used to detect the presence, direction, intensity, and character of blood flow in vessels. Its physical principle is based on the fact that the frequency of a wave reflected from a moving object is modified by a characteristic frequency shift, which is determined by the object's velocity relative to the wave source. This phenomenon was first described by Doppler (1842) and is called the "Doppler shift" or "Doppler effect." Different modes of Doppler USG that have been increasingly applied in bovine medicine include pulsed-waved Doppler USG (Starke et al., 2011; Müller et al., 2017), color Doppler USG (Pinaffi et al., 2017; Siqueira et al., 2019), and power Doppler USG (Bollwein et al., 2010; Brozos et al., 2012). Because of its high sensitivity for slow flow rates and flow in small vessels (Mattoon and Nyland, 2015), power Doppler USG is suitable to assess slow blood flow rates through a reportedly intertwined system of small blood vessels of cows' teats (Hamann and Burvenich, 1994). However, despite advancements in USG technology over the last few decades, power Doppler USG has not been rigorously used to assess changes in teat blood circulation that may occur during machine milking. Some pioneering work (Kuchler, 2011) has been conducted by a German research group, who concluded that changes in teat blood flow of dairy cows can be measured using power Doppler USG (Kuchler et al., 2011). Recently, we developed and evaluated a standardized technique to assess teat blood circulation in dairy cows using power Doppler USG (Wieland et al., 2019c). We found that precise measurements of blood flow could be achieved, given that a single operator obtained the measurements. A practical application of this technique could be the assessment of short-term changes in teat blood flow that result from machine milking. Such knowledge could further the understanding of how the blood circulation is affected by current machine milking practices. The primary objective of this study, therefore, was to describe machine milking-induced changes in teat blood circulation of dairy cows using power Doppler USG. We hypothesized that changes in teat blood flow would occur because of machine milking. Because previous research using different techniques indicated changes in blood flow associated with pre-milking udder stimulation (Houvenaghel et al., 1973; Paulrud et al., 2005), changes relative to pre-milking udder stimulation were also considered.

Differences in characteristics of the milking liner barrel design (i.e., round vs. multisided concave) can lead to differences in teat-end callosity, such that teats milked with a milking liner with a multisided concave barrel design have a lower incidence of teat-end callosity roughness (Haeussermann et al., 2016). The authors attributed this to various characteristics of the teat-liner interaction, including differences in the spatiotemporal distribution of the compressive load, total pressure area, and radial shear forces. Conversely, little information is available regarding the effect of different barrel designs on machine milking-induced changes in teat blood circulation. Therefore, our secondary objective was to study the effect of 2 different designs of milking liner barrels on ultrasonographically assessed changes in teat blood circulation. We hypothesized that differences in liner barrel design would affect machine milking-induced changes in blood circulation of dairy cows' teats.

\section{MATERIALS AND METHODS}

This randomized trial was conducted at the Teaching Dairy Barn at the Cornell University College of Veterinary Medicine (Ithaca, NY) between August and September 2019. The study protocol was reviewed and approved by the Cornell University Institutional Animal Care and Use Committee (protocol no. 2016-0112).

\section{Animals and Housing}

During the study period, a total of 154 lactating Holstein cows were housed in 2 freestall pens that were bedded with recycled sand. They were fed the same total mixed ration formulated to meet or exceed the requirements outlined by the National Research Council (2001). Herd data were maintained in a dairy management software program (Dairy Comp 305, Valley Agricultural Software, Tulare, CA). The farm used DHIA services including the individual-cow SCC option. The rolling herd key performance indicators were average milk production, $12,512 \mathrm{~kg}$; bulk tank SCC, 234,000 cells/mL; monthly clinical mastitis incidence, $2.4 \%$; 21-d pregnancy rate, $29 \%$; and culling rate, $37.9 \%$.

\section{Milking System}

Cows were milked 3 times per day at 0400, 1100, and $1900 \mathrm{~h}$ in a double-10 parallel milking parlor (P2100, 
DeLaval International AB, Tumba, Sweden). The vacuum pump $(7.5 \mathrm{~kW})$ was set to supply a receiver operator vacuum of $45 \mathrm{kPa}$ and regulated by a variable frequency drive. The milking unit was composed of the cluster MC70 (DeLaval International AB) and a milking liner with a square barrel shape (ProSquare DPX2, IBA, Millbury, MA). The pulsators (Delatron, DeLaval International $\mathrm{AB}$ ) were set to a pulsation rate of 60 cycles/min, a ratio of 70:30, and a side-to-side alternating pulsation. The pulsation phases were aphase, 123; b-phase, 572; c-phase, 99; and d-phase, 206 ms. These settings resulted in an average claw vacuum during peak milk flow period of $37.9 \mathrm{kPa}$. This value was calculated using the average cyclic vacuum fluctuations (assessed for 10 pulsation cycles $60 \mathrm{~s}$ after the start of the peak milk flow period) from 10 milking observations obtained with a digital vacuum recorder (VaDia, Biocontrol, Rakkestad, Norway). The automatic cluster removers were set to a cluster-remover milk-flow threshold of $1.4 \mathrm{~kg} / \mathrm{min}$, a 0 -s delay, and a vacuum decay time of $2.3 \mathrm{~s}$. The milk sweep was initiated $1.5 \mathrm{~s}$ after unit retraction and lasted for $4 \mathrm{~s}$. The milk line was installed $75 \mathrm{~cm}$ below cow standing level. The milking parlor was equipped with electronic on-farm milk meters using near-infrared technology (MM27BC, DeLaval International AB) for assessment of milking characteristics. Milking system settings and milking characteristics were monitored with a dairy farm management software program (DelPro, DeLaval International $\mathrm{AB}$ ). Before the start of the study, all system settings were verified and assessed by the investigators according to the guidelines outlined by the National Mastitis Council (2012).

\section{Sample Size Calculation}

The sample size calculation was performed for a repeated measures ANOVA for testing the interaction between a within-subjects variable and a betweensubjects variable in $\mathrm{G}^{*}$ Power (version 3.1.9.2; Faul et al., 2007). We chose a significance level of $\alpha=0.05$ and a power of $\beta \geq 0.95$. We determined a sample size of 166 was required, based on assumptions that (1) there was a correlation between measurements within a cow of 0.35 , (2) the sphericity assumption was met, (3) 3 repeated measurements were taken, and (4) there was a conservative effect size (partial $\eta^{2}=0.02$ ). To account for clustering of teats within a cow, an adjustment to the original sample size was made according to Dohoo et al. (2009), using a presumed intraclass correlation coefficient of 0.25 . The adjusted sample size of 104 cows was then inflated by a factor of 0.05 because of an as- sumed attrition rate of $5 \%$, resulting in a pre-exclusion sample size of 110 cows.

\section{Eligibility Criteria and Treatment Allocation}

Lactating cows were eligible for enrollment if they were free of clinical mastitis for at least $2 \mathrm{wk}$, had no udder abnormalities such as nonlactating quarters or teat injuries, and had a record of normal ease of handling. Because standing time was anticipated to be increased during the experimental milkings, cows were also required to be free of lameness. Eligible cows were randomly assigned to 1 of 2 treatment groups, stratified by parity, DIM, and average daily milk yield during the previous week, following the sequence generated by a random-number generator (Urbaniak and Plous, 2013). Treatments consisted of 2 different milking liners (Clover 12R+, group CL, and LS-01 R12, group LS; DeLaval International AB) and were applied during 1 experimental milking using the same machine settings as described above. Table 1 depicts characteristics, dimensions, duration of pulsation phases under load, and mean values for the average claw vacuum during the peak milk flow period of both experimental milking liners.

\section{Experimental Milking}

To minimize interference with the dairy's milking schedule, study cows were milked between 1715 and

Table 1. Descriptive data on experimental milking liners

\begin{tabular}{|c|c|c|}
\hline \multirow[b]{2}{*}{ Item } & \multicolumn{2}{|c|}{ Milking liner ${ }^{1}$} \\
\hline & $\mathrm{CL}$ & LS \\
\hline Mouthpiece bore diameter (mm) & 20.3 & 20.3 \\
\hline Mouthpiece depth (mm) & 27 & 33 \\
\hline Barrel length (mm) & 113 & 113 \\
\hline Barrel shape & multisided concave & round \\
\hline Barrel diameter at $75 \mathrm{~mm}(\mathrm{~mm})$ & 22.6 & 21.8 \\
\hline \multicolumn{3}{|l|}{ Duration of pulsation phases ${ }^{2}(\mathrm{~ms})$} \\
\hline a-phase & 135 & 125 \\
\hline b-phase & 558 & 573 \\
\hline c-phase & 107 & 97 \\
\hline d-phase & 200 & 205 \\
\hline Mean average claw vacuum ${ }^{2}(\mathrm{kPa})$ & 38.6 & 38.9 \\
\hline
\end{tabular}

${ }^{1} \mathrm{CL}=$ Clover $12 \mathrm{R}+$; LS = LS-01 R12 (both from DeLaval International AB, Tumba, Sweden).

${ }^{2}$ Values obtained with a digital vacuum recorder (VaDia, Biocontrol, Rakkestad, Norway) from additional non-experimental milking observations using the dairy's standard machine settings (i.e., receiver operating vacuum, $45 \mathrm{kPa}$; pulsation rate, 60 cycles $/ \mathrm{min}$, pulsation ratio, 75:35). Mean average claw vacuum during peak milk flow period calculated from the average cyclic vacuum fluctuations from 15 milking observations. 
$1900 \mathrm{~h}$ on 11 consecutive days (Aug. 26 to Sept. 5, 2019). For this purpose, 10 enrolled cows ( 5 cows per treatment group) were selected from the enrollment list each day, segregated from their herd mates, and moved to the milking parlor 15 min before the experimental milking began. To accommodate the laborious activities associated with the ultrasonographic scanning and facilitate timely scanning after unit detachment, experimental milkings were performed sequentially. The milking order was determined by the order the cows entered the milking parlor. Treatment was administered by installation of a milking unit that was equipped with the respective milking liner. Pre-milking udder preparation and teat sanitization consisted of 3 steps: step 1 was to wipe all 4 teats with separate clean cloth towels and dip the teats with an iodine-based teat dip (Multi Dose MD, DeLaval International AB); step 2 was to forestrip and dry all 4 teats with separate clean cloth towels; and step 3 was to attach and align the milking unit.

\section{Teat Characteristics}

Descriptions of teat characteristics (teat length, teat diameter, and teat-end shape) were recorded 1 to 5 $\mathrm{d}$ before the experimental milking. Measurements and teat-end shape evaluation were obtained after completion of pre-milking udder preparation but before milking unit attachment, as previously described (Wieland et al., 2017; Melvin et al., 2019). Teat length was measured from the teat base to the teat end with a digital depth gauge (SKU 303-1752, Shars Tool Company, St. Charles, IL). Teat diameter was assessed at the midpoint between the teat base and the teat end using a digital caliper (75-TM54006, Vernier, Beaverton, OR). For subsequent analyses, a new variable (i.e., teat size) was created, based on the dimensions of the milking liners used in the study, and classified into 1 of 3 categories: small, with teat length $\leq 37 \mathrm{~mm}$ or teat diameter $<23 \mathrm{~mm}$; moderate, with teat length $>37 \mathrm{~mm}$ and teat diameter $23-25 \mathrm{~mm}$; or large, with teat length $>37 \mathrm{~mm}$ and teat diameter $>25 \mathrm{~mm}$. Teat-end shape was classified into categories as pointed, flat, or round.

Teat-end callosity was scored on the day of enrollment, according to the scoring system outlined by Teat Club International (Mein et al., 2001) and classified into 4 score categories. Score 1 indicates no callosity ring is present; score 2 indicates there is a callosity ring but no roughness present; score 3 indicates a callosity ring and roughness are present, with keratin fronds extending 1 to $3 \mathrm{~mm}$ from the teat orifice; and score 4 indicates a callosity ring is present, with excessive keratin fronds extending $\geq 4 \mathrm{~mm}$ from the teat orifice. For subsequent analyses, teat-end callosity was dichotomized as hy- perkeratosis absent (scores 1 and 2) or hyperkeratosis present (scores 3 and 4).

\section{Ultrasonographic Technique}

Power Doppler USG of the left front and the right hind teats was performed by a trained investigator (MW) with a portable ultrasound device (Logiq e Vet NextGEN, General Electric, Boston, MA) with a 6 to $13 \mathrm{MHz}$ linear-array transducer (12L-RS, General Electric). Consistent optimal imaging modes were used throughout the study. The B-mode settings were frequency, $12 \mathrm{MHz}$; gain, 42; and depth, $3.5 \mathrm{~cm}$. The power Doppler imaging mode settings were frequency, $7.7 \mathrm{MHz}$; gain, 20; L/A (line density), 2/5; pulse repetition frequency, 1.5; wall filter, 212; and S/P (spatial filter), 2/12. Transverse teat scans were taken from the caudal aspect of the teat with the transducer held horizontally in a caudocranial direction. To avoid teat deformation, the teat was immersed in a rectangular plastic container $(130 \times 60 \times 60 \mathrm{~mm})$. The container was filled with approximately $400 \mathrm{~mL}$ of warm $\left(30^{\circ} \mathrm{C}\right)$ $1.0 \%$ chlorhexidine lube (Chem Select Inc., Rancho Santa Margarita, CA). To facilitate manipulation of the transducer and container, 2 wooden dowels were attached to the container such that the transducer would fit tightly between both dowels minimizing its mobility. This procedure standardized the position of scanning to approximately $2 \mathrm{~cm}$ below the teat base. Ultrasound gel (Medline Industries Inc., Northfield, IL) was used as a coupling medium. Figures 1 and 2 exemplify the scanning procedure and a transverse teat scan.

Teat scans were taken before initiation of pre-milking udder preparation (T1), after completion of pre-milking udder preparation but before milking-unit attachment (T2), and immediately after unit detachment (T3). Ultrasonographic scanning at T2 began between 80 and $90 \mathrm{~s}$ after initiation of forestripping. Scanning and subsequent drying of teats resulted in a preparation lag time (i.e., time spent from first strip until milking-unit attachment) of approximately $160 \mathrm{~s}$ (mean \pm SD: 159 \pm 30 , range: $97-255$ ). Teat scanning at T3 commenced approximately $15 \mathrm{~s}$ after milking-unit detachment and took approximately 2 to $3 \mathrm{~min}$. After completion of teat scanning at T3, residual chlorhexidine lube was removed with a separate clean cloth towel and postmilking teat dip (Multi Dose MD; DeLaval International AB) was applied.

\section{Blood Perfusion Intensity Measurements}

A trained investigator (SS), who was blinded to the treatment, used video images to perform perfusion in- 


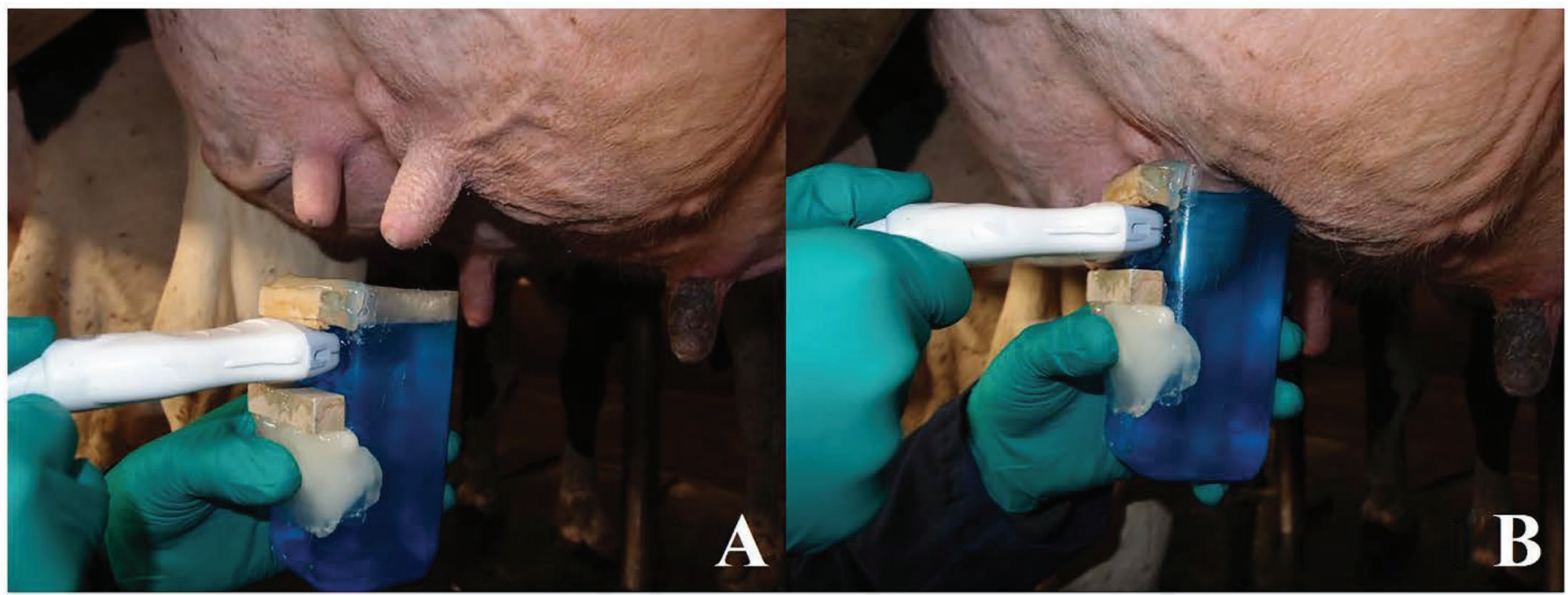

Figure 1. Ultrasonographic scanning technique using a rectangular plastic container $(130 \times 60 \times 60 \mathrm{~mm})$. The container was filled with approximately $400 \mathrm{~mL}$ of warm $\left(30^{\circ} \mathrm{C}\right) 1.0 \%$ chlorhexidine lube (Chem Select Inc., Rancho Santa Margarita, CA). Two wooden dowels were attached to the container to facilitate manipulation of the transducer (12L-RS, General Electric, Boston, MA) and the container. Panel A depicts the ultrasonographic setup before immersion of the teat; panel B illustrates the setup after immersion of the teat.

tensity measurements using a commercially available software program (PixelFlux, Chameleon-Software, Münster, Germany), according to the method reported by Scholbach et al. (2012). The steps were performed

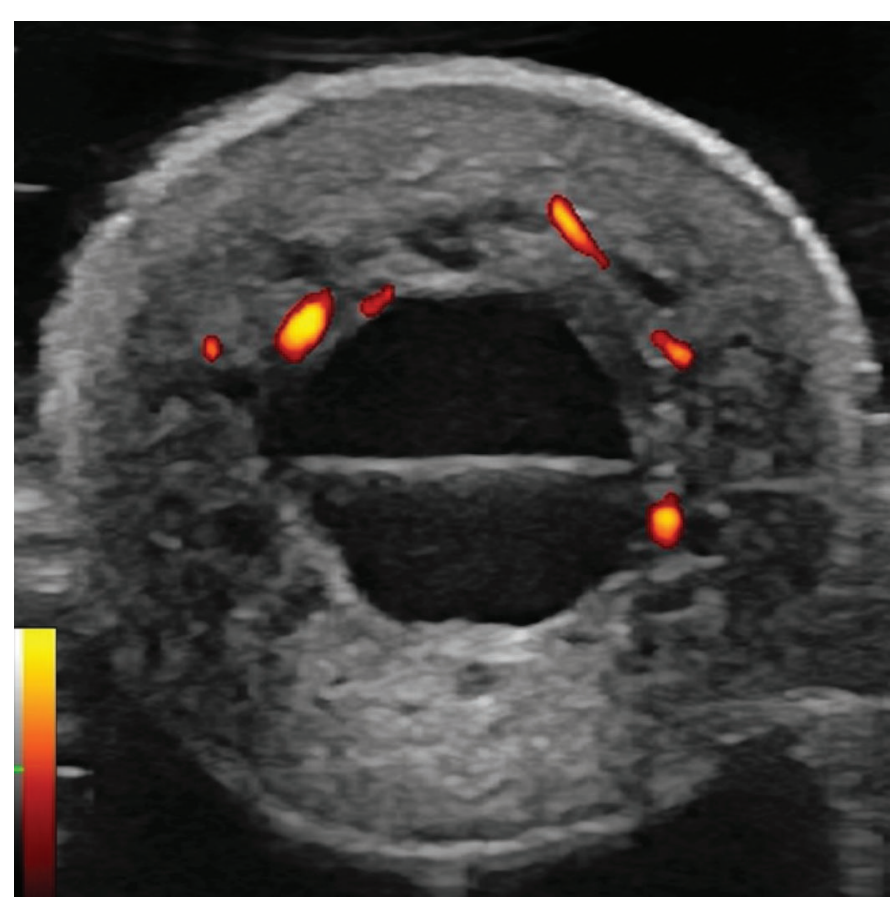

Figure 2. Transverse teat scan of the right hind teat. The image was taken directly after unit detachment with a portable ultrasound device (Logiq e Vet NextGEN, General Electric, Boston, MA) and a 4.2- to 13-MHz linear array transducer (12L-RS, General Electric) using power Doppler mode. consistently for each individual analysis and followed a standard operating procedure developed before the study (Wieland et al., 2019c). First, the sequence of video images subjected to analysis was identified by visual inspection. For this purpose, each video clip was visually investigated for motion artifacts (i.e., color hues that appeared outside the boundary of the external teat wall or within the teat cistern). Consequently, the analysis of each scan was performed on 1 selected sequence of consecutive video images from each video clip. Second, the scale was calibrated using the scale imprinted on the sonographic image (i.e., distance between 2 dots representing a total distance of $1 \mathrm{~cm}$ ). Third, the proper positioning of the color scale alongside the color bar via the automatic recognition was confirmed. Fourth, the coloration representing the maximum Doppler signal was set to $100 \%$. Thus, each color hue on the color bar was assigned an individual power Doppler signal value between $0 \%$ and $100 \%$. Last, the region of interest subjected to computation $\left(\mathbf{R O I}_{\mathbf{P F x}}\right)$ was outlined with the integrated drawing tool and defined by the teats' circumference. Based on these settings, the power Doppler signal value for each individual pixel inside the $\mathrm{ROI}_{\mathrm{PFX}}$ was calculated by comparison of its color hue with the color hues of the image color bar $(0$ to $100 \%$ ) and computation of its area. In the next step, the colored area inside the $\mathrm{ROI}_{\mathrm{PFx}}$ was calculated by referring the sum of all colored pixel area values to the entire $\mathrm{ROI}_{\mathrm{PFX}}$. Subsequently, the mean power Doppler signal of the entire $\mathrm{ROI}_{\mathrm{PFx}}$ was calculated by relating the sum of all colored pixel signal values to the entire $\mathrm{ROI}_{\mathrm{PFX}}$. Finally, the perfusion intensity was calculated 
by multiplication of the mean power Doppler signal of all pixels inside the $\mathrm{ROI}_{\mathrm{PFX}}$ with the area occupied by all colored pixels inside the $\mathrm{ROI}_{\mathrm{PFx}}$. Perfusion intensity was expressed in percentage, where a value of $100 \%$ represented an $\mathrm{ROI}_{\mathrm{PFX}}$ filled with colored pixels at a maximum-power Doppler signal level.

\section{Analytical Approach}

Data were maintained in a commercially available spreadsheet (Microsoft Office Excel 2013, Microsoft Corporation, Redmond, WA) and analyzed using SAS 9.4 (SAS Institute Inc., Cary, NC).

Baseline Characteristics. Boxplots were generated in PROC UNIVARIATE to visually assess normality of continuous variables. Descriptive statistics were generated with PROC MEANS and PROC FREQ. Pearson chi-squared tests were generated using PROC FREQ to assess differences between treatment groups in parity, teat size (for the right hind position), teatend shape, and hyperkeratosis (for left front teats). The Fisher-exact test was computed in PROC FREQ to evaluate differences in teat size for left front teats and hyperkeratosis for right hind teats. Differences in DIM, SCC from the previous test date ( $\log _{10}$ transformed, $\operatorname{logSCC})$, teat length, teat diameter, milk yield $(\mathrm{kg}$, MY), average milk flow rate $(\mathrm{kg} / \mathrm{min} ; \mathbf{A M F})$, and milking unit on time (s, MUOT) were assessed with Student's $t$-test using PROC TTEST. Wilcoxon rank sum test was calculated in PROC NPAR1WAY to assess differences in time spent in low $(<1 \mathrm{~kg} / \mathrm{min})$ milk flow rate (s, LMF) between treatment groups.

Model. A general linear mixed model was fitted with PROC MIXED to study changes of blood perfusion intensity over the 3 different time points and its association with treatment. Enrollment block (d 1-11) was included as random effect. To account for dependence of repeated measurements over time, a REPEATED statement for quarter position nested within cow was included. Four covariance structures were tested (compound symmetry, variance components, autoregressive order 1, and unstructured) to model the covariance of repeated measurements, and the one with the smallest Akaike's information criterion was selected. Treatment group, time point, and their interaction were forced into the model as fixed effects. Additional independent variables were considered as covariates and screened for inclusion into the model initially through univariable analysis, including parity (first, second, and $\geq$ third lactation), stage of lactation ( $\leq 100,101-200,>200$ DIM), $\operatorname{logSCC}$, quarter position (left front and right hind), teat length $(\mathrm{mm})$, teat diameter $(\mathrm{mm})$, teat size (small, moderate, and large), teat-end shape (pointed, flat, and round), and hyperkeratosis (absent and present).
All variables with a $P$-value $<0.20$ in this step were considered covariates in the initial multivariable model. Collinearity among eligible variables was assessed by calculating Spearman correlation coefficients in PROC CORR. A coefficient of $>|0.50|$ was considered to indicate collinearity. No collinearity was observed among the variables parity, stage of lactation, and teat-end shape. Manual backward elimination was performed until each of the covariates had a $P$-value $<0.05$ to establish the final model. Confounding effects were monitored by observing regression coefficient changes. Variables that modified regression coefficients by $>20 \%$ were considered confounding factors. No confounding was observed. Two-way interactions between all remaining variables were tested and remained in the model if $P$-value $<0.05$. Tukey-Kramer's post hoc test was used to control for the experimental error rate. Cook's distance was calculated with the INFLUENCE option to estimate the influence of outliers. A value of $>0.5$ was considered to indicate an influential value. No influential data values were observed. For the final model, the assumptions of homoscedasticity and normality of residuals were assessed by the inspection of residual plots versus corresponding predicted values and the examination of quantile-quantile residual plots. To satisfy these assumptions, data of the dependent variable blood perfusion intensity were log-transformed. The resulting least squares means estimates were consequently back transformed and presented as the geometric mean and 95\% CI.

\section{RESULTS}

\section{Description of Study Population}

A total of 110 cows were enrolled in the study. Data from 1 cow were excluded due to erroneous treatment allocation. The average (mean \pm SD) DIM was $146 \pm$ 103 d ranging from 9 to 460 d. Parity was distributed as follows: $46(42.2 \%)$ animals were in first, $44(40.4 \%)$ were in second, and $19(17.4 \%)$ were in third or greater lactation (10 in third lactation; 4 in fourth lactation; and 5 in fifth lactation). Average [mean $\pm \mathrm{SD}$ (median; range)] teat lengths and diameters, respectively, were left front, $53.4 \pm 7.3(54 ; 35-78)$ and $27.9 \pm 3.5(27$; 21-40) $\mathrm{mm}$; and right hind, $43.6 \pm 6.8(43 ; 25-62)$ and $26.3 \pm 3.5(26 ; 20-40) \mathrm{mm}$. Frequency distribution for pointed, flat, and round teat-end shapes, respectively, were left front $11(10.1 \%), 24(22.0 \%)$, and $73(67 \%)$; and right hind 11 (10.1\%), $24(22.0 \%)$, and $74(67.9 \%)$. Hyperkeratosis was documented in 19 (17.4\%) left front and $7(6.4 \%)$ right hind teats. During the experimental milkings, average [mean \pm SD (median; range)] MY, AMF, MUOT, and LMF, respectively, were $9.6 \pm 2.6$ 
Table 3. Blood perfusion intensity (\%) of the left front and right hind teats of 109 Holstein dairy cows

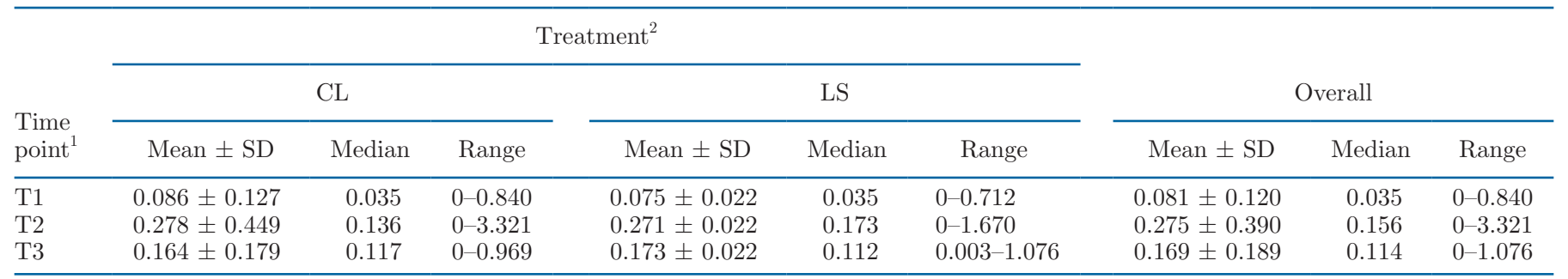

${ }^{1} \mathrm{~T} 1=$ before initiation of pre-milking udder preparation; T2 = after completion of pre-milking udder preparation but before milking unit attachment; T3 = immediately after unit detachment.

${ }^{2}$ Treatments consisted of 1 milking observation with 1 of 2 milking liners; CL = Clover 12R +; LS = LS-01 R12 (both DeLaval International AB, Tumba, Sweden).

Treatment had no effect on blood perfusion intensity $(P=0.50)$. Teat blood perfusion intensity (LSM, $95 \%$ $\mathrm{CI})$ at $\mathrm{T} 1, \mathrm{~T} 2$, and $\mathrm{T} 3$, respectively, was $0.035(0.026-$ $0.047), 0.124(0.093-0.164)$, and $0.095(0.073-0.124)$ $\%$ (Table 4). Tukey-Kramer's post hoc test revealed differences between all 3 time points $(P \leq 0.05)$. Cows in mid-lactation (101-200 DIM) had higher blood perfusion $(0.106 \%, 0.075-0.150)$ compared with latelactation (>200 DIM) animals $(0.059 \%, 0.040-0.087$, $P=0.04)$. By contrast, no statistically significant differences were detected between early-lactation $(\leq 100$ DIM) animals $(0.066 \%, 0.048-0.092)$ and mid-lactation animals $(P=0.06)$ and between cows in early- and late-lactation $(P=0.87)$. Figure 3 illustrates the blood perfusion intensity at the 3 different time points stratified by treatment group.

\section{DISCUSSION}

\section{Changes of Blood Perfusion Intensity over Time}

Our primary objective in the current study was to describe changes in teat blood circulation that occur after pre-milking teat stimulation and machine milking. For this purpose, we employed power Doppler sonography and quantified the power Doppler signal using a specially designed software program for perfusion measurements. Our results show that teat blood

Table 4. Factors associated with blood perfusion intensity (\%) of the left front and right hind teats of 109 Holstein dairy cows

\begin{tabular}{|c|c|c|c|}
\hline Item & $\beta^{1}(\mathrm{SE})$ & $P$-value & LSM (95\% CI) \\
\hline Intercept & $-2.58(0.20)$ & $<0.0001$ & - \\
\hline Treatment $^{2}$ & & 0.50 & \\
\hline CL & $-0.011(0.16)$ & & - \\
\hline LS & Referent & & - \\
\hline Time $^{3}$ & & $<0.0001$ & \\
\hline $\mathrm{T} 1$ & $-0.99(0.16)^{\mathrm{a}}$ & & $0.035(0.026-0.047)$ \\
\hline $\mathrm{T} 2$ & $0.37(0.16)^{\mathrm{b}}$ & & $0.124(0.093-0.164)$ \\
\hline $\mathrm{T} 3$ & Referent $^{\mathrm{c}}$ & & $0.095(0.073-0.124)$ \\
\hline Stage of lactation & & 0.02 & \\
\hline$\leq 100$ DIM & $0.12(0.23)^{\mathrm{ab}}$ & & $0.066(0.048-0.092)$ \\
\hline 101-200 DIM & $0.58(0.23)^{\mathrm{b}}$ & & $0.106(0.075-0.150)$ \\
\hline$>200$ DIM & Referent $^{\mathrm{a}}$ & & $0.059(0.040-0.087)$ \\
\hline Treatment $\times$ Time & & 0.58 & \\
\hline $\mathrm{CL} \times \mathrm{T} 1$ & $-0.02(0.23)$ & & $0.035(0.025-0.048)$ \\
\hline $\mathrm{LS} \times \mathrm{T} 1$ & Referent & & $0.036(0.025-0.050)$ \\
\hline $\mathrm{CL} \times \mathrm{T} 2$ & $-0.22(0.22)$ & & $0.110(0.079-0.154)$ \\
\hline $\mathrm{LS} \times \mathrm{T} 2$ & Referent & & $0.139(0.099-0.195)$ \\
\hline $\mathrm{CL} \times \mathrm{T} 3$ & Referent & & $0.095(0.070-0.128)$ \\
\hline $\mathrm{LS} \times \mathrm{T} 3$ & Referent & & $0.096(0.071-0.130)$ \\
\hline
\end{tabular}

${ }^{a-c}$ Groups with different superscript letters differ at a level of $P \leq 0.05$ in Tukey-Kramer's post hoc test.

${ }^{1}$ Linear regression coefficient.

${ }^{2}$ Treatments consisted of 1 milking observation with 1 of 2 milking liners; CL = Clover 12R+; LS = LS-01 R12 (both DeLaval International AB, Tumba, Sweden).

${ }^{3} \mathrm{~T} 1$ = before initiation of pre-milking udder preparation; $\mathrm{T} 2=$ after completion of pre-milking udder preparation but before milking unit attachment; T3 = immediately after unit detachment. 
circulation increased after pre-milking teat stimulation, which is consistent with findings from Houvenaghel et al. (1973). The researchers investigated the influence of udder stimulation on mammary blood flow, using an electromagnetic flowprobe that was implanted around the external pudendal artery of one udder half in 6 lactating cows. They documented a definite increase in udder artery blood flow within $40 \mathrm{~s}$ after commencement of udder stimulation that ranged from 20 to $288 \%$ in the majority $(126 / 138)$ of the observations. Several possible factors may underlie the observed increase in teat blood circulation following pre-milking teat stimulation. First, teat stimulation decreases the sympathetic tone of the mammary gland, yielding to a vasodilation and consecutive increase in blood flow (Lefcourt, 1982). Second, during milk ejection, oxytocin-induced contractions of myoepithelial cells may remove pressure on capillary beds, thereby decreasing the resistance to blood flow (Lefcourt, 1982). Last, the rate and amplitude of contractions of muscle surrounding the teat and teat canal decreases during manual teat stimulation (Lefcourt, 1982). Teat muscle contractions have been reported to decrease arterial blood flow to the teat end (Maltz et al., 2000). A decrease in their amplitude and frequency after pre-milking teat stimulation may therefore increase sonographically detectable teat blood circulation.

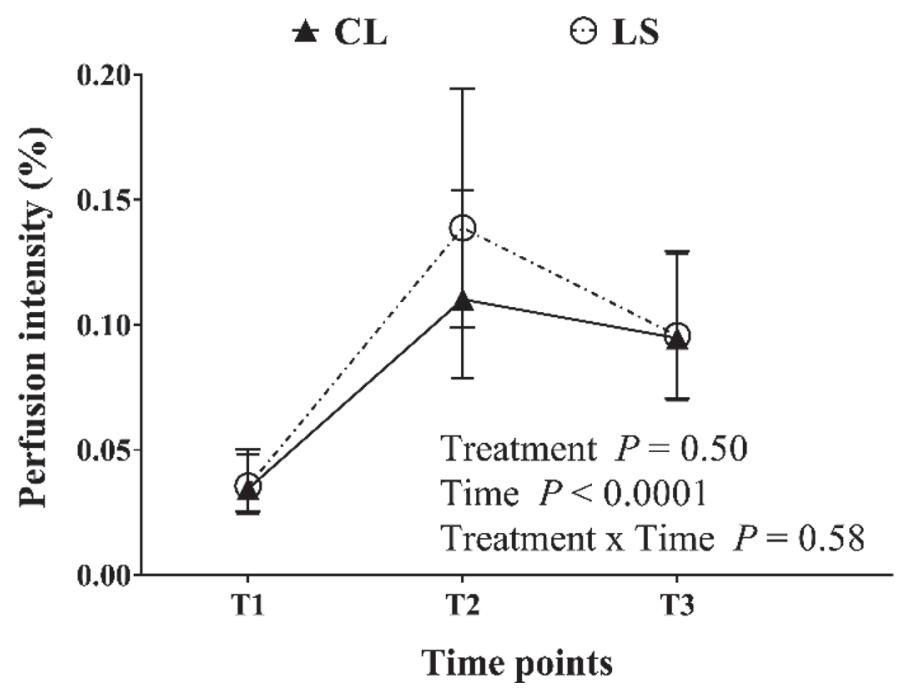

Figure 3. Ultrasonographically (power Doppler) assessed blood perfusion intensity of the left front and right hind teats of 109 Holstein dairy cows milked with 2 different milking liners $(\mathrm{CL}=$ Clover $12 \mathrm{R}+$; LS = LS-01 R12; both DeLaval International AB, Tumba, Sweden) before initiation of pre-milking udder preparation (T1), after completion of pre-milking udder preparation but before milking-unit attachment (T2), and directly after unit detachment (T3). Results presented as least squares means from a general linear mixed model. Error bars show $95 \%$ confidence intervals.
By contrast, Paulrud et al. (2005) found that teat-skin temperature, as measured with infrared thermography, decreased after pre-milking teat stimulation. The authors attributed the observed drop in heat dissipation to (1) a decrease in blood volume following removal of venous blood during teat stimulation, (2) a decrease in tissue blood flow due to a reduction in rate and amplitude of teat and teat-sphincter-muscle contractions following teat stimulation, and (3) the activation of the autonomous nervous system via mechano- and thermoreceptor in the teat skin, leading to vasoconstriction of the cutaneous vascular plexus surrounding the teat. Other researchers investigating machine milking-induced changes in teat blood circulation using different measuring techniques such as infrared thermography (Barkova et al., 2019; Tangorra et al., 2019), laser Doppler flowmetry (Persson, 1991; Hamann et al., 1994a), or power Doppler sonography (Kuchler, 2011) did not describe changes in blood flow associated with pre-milking teat stimulation.

We found that teat blood circulation decreased after machine milking, compared with the value after completion of pre-milking udder preparation (T2). We hypothesize that the observed alteration was due to vacuum-induced mechanical forces during machine milking evoking circulatory impairment of the teat. We base this hypothesis on previous work from our own group (Wieland et al., 2018, 2019a,b) and reports from other researchers (Upton et al., 2016; Penry et al., 2017; Odorčić et al., 2019) that conform to the idea of a machine milking-induced effect on the circulatory system of the teat. Our findings are therefore of particular importance, as they describe an immediate quantification of changes in teat blood circulation that occur during machine milking. Kuchler (2011) reported a decrease in teat blood perfusion intensity after machine milking. The author attributed the observed changes to the effects of machine milking on the teat tissue and vascularization, which is consistent with our theory. This is supported further by the work of Hamann et al. (1994a), who reported that differences in the changes of teat skin blood flow were dependent on the machine settings. The researchers investigated the effect of 4 different milking conditions on teat skin blood flow using laser Doppler flowmetry. Milking systems consisted of conventional milking with a wide-bore diameter milking liner, a narrow-bore diameter milking liner, a system with positive pressure (pulsation chamber during d-phase $35 \mathrm{kPa}$ above atmospheric pressure), and a system without pulsation. Teat-skin blood flow was measured for 5 min before pre-milking udder preparation commenced and for 5 min after milking unit detachment. They found increased blood flow after milking (compared with the pre-milking values) when 
cows were milked with the narrow-bore milking liner and the positive pressure system; whereas, teat-skin blood flow after milking was lower in cows being milked with the wide-bore diameter milking liner and the pulsationless milking system. The authors suggested that the increased teat-skin blood flow in cows milked with the narrow-bore milking liner and the positive pressure system was due to a "reactive hyperemia," a tissue reaction to compensate for the mechanical impact during machine milking. They further attributed the observed decrease in teat-skin blood flow in cows milked with the wide-bore diameter milking liner and the pulsationless milking system to fluid accumulation (i.e., congestion and edema) at the aspect of the teat barrel interfering with the microcirculation in the teat skin (Hamann et al. 1994a).

In this study, stage of lactation was associated with teat blood perfusion intensity, such that mid-lactation animals had higher blood circulation compared with late-lactation animals. A possible explanation for the observed phenomenon is that machine milking induces changes in teat tissue composition over time. Hamann and Burvenich (1994) reported that accumulation of edema fluid and lymphatic by-products may lead to collagen deposition and fibrosis of the teat tissue. This could reduce tissue vascularization with advancing stage of lactation.

\section{Milking Liner Comparison}

Our secondary objective was to study the effect of 2 different milking-liner design characteristics on teat blood circulation: Our results do not support a measurable difference between the 2 different milking liners, CL and LS. We attribute the absence of a meaningful difference to the similarity in liner dimensions, which likely led to a similar circulatory impairment during machine milking. Previous work using infrared thermography has shown an effect of milking-liner type on teat-skin temperature (Paulrud et al., 2005). The Danish researchers milked 8 Danish Holstein cows with 2 different milking liners on their hind teats. Thermographic imaging of hind teats was performed before pre-milking udder preparation, after preparation, and immediately after milking. They found a decrease in teat-skin temperature in both treatment groups and that post-milking teat-skin temperature was dependent upon the milking liner used.

When comparing different studies, one has to keep in mind the differences in study design, study population, and measuring technique. The infrared thermography that has been used by previous groups (Paulrud et al., 2005; Barkova et al., 2019; Tangorra et al., 2019) measures teat-skin temperature as an indirect esti- mate of blood circulation of the teat skin. Similarly, the laser Doppler flowmetry as employed by Hamann et al. (1994a) quantifies blood flow of the teat skin. Conversely, blood flow of the underlying tissue is not assessed with either of the 2 measuring techniques. Because both circulatory systems may underlie different mechanisms of blood flow regulation throughout a milking event, a direct comparison of these previous studies with the current one cannot be made.

\section{Study Limitations and Future Directions}

Although our findings are encouraging for the further investigation of machine milking-induced changes in teat blood circulation, our study had several limitations. First, study cows were milked up to $105 \mathrm{~min}$ before the regular start time of milking, stood in the parlor for a longer period of time than usual, and were surrounded by unfamiliar activities. Teats were also repeatedly immersed in warm chlorhexidine lube as part of the ultrasound procedure. These factors may have had an effect on sympathetic tone of the mammary gland, thus potentially interfering with teat blood circulation. Second, data were collected during 1 experimental milking without application of an adjustment period (i.e., "wash-out"). We therefore cannot exclude a carryover effect of the previous milking on teat blood circulation. However, we believe that if such a carryover effect had existed, it would have been applied equally to both treatment groups as all cows were milked with the same milking liner type before the experimental milking. Third, as demonstrated by Maltz et al. (2000), teat blood flow may be influenced ultimately by teat muscle contractions, which we failed to consider in this study, in an effort to obtain timely teat scans after completion of pre-milking teat stimulation and immediately after machine milking. This may have increased the proportion of the unexplained variability in our model. Last, although we are showing a temporal association between the changes in teat blood circulation and the milking event, we cannot demonstrate a causal relationship.

Teat blood circulation is essential for maintenance and recovery of teat tissue integrity during and after machine milking (Maltz et al., 2000). It is paramount to facilitate secretion of antimicrobial substances, ensure cellular replacement of epithelial cells to recover the stratum corneum of the teat canal, and nourish immune cells located at the adjacent Furstenberg's rosette (Nickerson and Pankey, 1983; Jankus and Baumann, 1986; Paulrud, 2005). These structures form the first defense line against mastitis pathogens entering the mammary gland via the teat canal. Thus, opportunities for additional research in this area abound. Future stud- 
ies investigating a causal relationship between machine milking and teat blood circulation are warranted. Such studies should investigate the relationship between changes in teat blood flow during machine milking and how they relate to the teats' defense mechanisms. Because blood flow may change during the course of a machine milking event, novel techniques that capture these alterations with an inherent in-line device are needed. To demonstrate differences between different machine settings, differences of larger magnitude than those used in the current study may be needed. These innovations also may help further our understanding of the teat-liner interaction and improve the milk harvesting process.

\section{CONCLUSIONS}

Teat blood circulation was associated with pre-milking teat stimulation and machine milking. We conclude that the circulatory system of dairy cows' teats is subjected to a multitude of influences including inherent circulatory regulation mechanisms and extrinsic factors such as machine milking. Future research is warranted to decipher these factors and further our understanding of how they are related to susceptibility to intramammary infection and milking performance.

\section{ACKNOWLEDGMENTS}

The authors thank the staff at the Cornell Teaching Dairy Barn (Ithaca, NY). We gratefully acknowledge the technical assistance from Keith Wacker from Sound Technologies Inc. (Carlsbad, CA). We thank Lauren Hardy (Ithaca, NY) for assisting with the documentation of the ultrasonographic technique. The experimental milking liners were provided by DeLaval International AB (Tumba, Sweden). Any opinions, findings, and conclusions revealed in this publication are those of the authors and do not necessarily reflect the position of the company. The authors have not stated any conflicts of interest.

\section{REFERENCES}

Barkova, A., A. Elesin, I. Milshtein, and M. Barashkin. 2019. Thermovision diagnostics of the milking equipment impact on the state of mammary glands of cattle. Adv. Intell. Syst. Res. 167:519-521. https://doi.org/10.2991/ispc-19.2019.116.

Bollwein, H., D. Prost, S. E. Ulbrich, H. Niemann, and A. Honnens. 2010. Effects of a shortened preovulatory follicular phase on genital blood flow and endometrial hormone receptor concentrations in Holstein-Friesian cows. Theriogenology 73:242-249. https://doi .org/10.1016/j.theriogenology.2009.08.014.

Brozos, C. N., M. S. Pancarci, J. Valencia, N. Beindorff, G. Tsousis, E. Kiossis, and H. Bollwein. 2012. Effect of oxytocin infusion on luteal blood flow and progesterone secretion in dairy cattle. J. Vet. Sci. 13:67-71. https://doi.org/10.4142/jvs.2012.13.1.67.
Dohoo, I. R., S. W. Martin, and H. Stryhn. 2009. Sampling. Pages 33-56 in Veterinary Epidemiologic Research. Vol. 1. 2 ed. I. R. Dohoo, S. W. Martin, and H. Stryhn, ed. AVC Inc., Charlottetown, PE, Canada

Doppler, C. 1842. Über das farbige Licht der Doppelsterne und einiger anderer Gestirne des Himmels (On the colored light of the binary stars and some other stars of the heavens). Pages 465-482 in Proc. Royal Bohemian Society of Sciences, Prague, Czech Republic.

Eichel, H. 1992. Zum Verhalten der Temperatur der Zitzenhaut von Milchkühen, die mit Rohrmelkanlage gemolken wurden. Monatsh. Veterinarmed. 47:193-195.

Faul, F., E. Erdfelder, A. G. Lang, and A. Buchner. 2007. G*Power 3: A flexible statistical power analysis program for the social, behavioral, and biomedical sciences. Behav. Res. Methods 39:175-191. https://doi.org/10.3758/BF03193146.

Guarín, J. F., and P. L. Ruegg. 2016. Short communication: Pre- and post-milking anatomical characteristics of teats and their associations with risk of clinical mastitis in dairy cows. J. Dairy Sci. 99:8323-8329. https://doi.org/10.3168/jds.2015-10093.

Haeussermann, A., J. Britten, A. Britten, C. Pahl, N. Alveby, and E. Hartung. 2016. Effect of a multi-sided concave liner barrel design on thickness and roughness of teat-end hyperkeratosis. J. Dairy Res. 83:188-195. https://doi.org/10.1017/S0022029916000200.

Hamann, J., and C. Burvenich. 1994. Physiological status of the bovine teat. Bull. Int. Dairy Fed. 297:3-12.

Hamann, J., C. Burvenich, M. Mayntz, O. Osteras, and W. Haider. 1994b. Machine-induced changes in the status of the bovine teat with respect to the new infection risk. Bull. Int. Dairy Fed. $297: 13-22$

Hamann, J., and G. A. Mein. 1990. Measurement of machine-induced changes in thickness of the bovine teat. J. Dairy Res. 57:495-505. https://doi.org/10.1017/S002202990002954X.

Hamann, J., B. Nipp, and K. Persson. 1994a. Teat tissue reactions to milking: Changes in blood flow and thickness in the bovine teat. Milchwissenschaft 49:243-247.

Houvenaghel, A., G. Peeters, and F. Verschooten. 1973. Influences of manual udder stimulation and oxytocin on mammary artery blood flow in lactating cows. Arch. Int. Pharmacodyn. Ther. 205:124133.

Jankus, E. F., and L. E. Baumann. 1986. Blood flow to the distal part of the teat (mammary papilla) of lactating dairy cows. Am. J. Vet. Res. 47:283-285.

Kuchler, K. 2011. Investigation of the effects of milking on the teat tissue and the teat blood flow using ultrasonographic scanning and color angiography [Der Einfluss des Melkens auf Durchblutung und Morphologie der Rinderzitze untersucht mittels Color Angiographie und B-Mode Sonographie]. in Zentrum für Klinische Tiermedizin der Tierärztlichen Fakultät. Vol. Dr. Vet. Med. Ludwig-Maximilians-Universität München, Munich.

Kuchler, K., Carola, S. L., R. Martin, and R. Mansfeld. 2011. Measuring the blood flow of teats of dairy cows by using color-angiography. Reprod. Domest. Anim. 44:25. https://doi.org/10.1111/j .1439-0531.2011.01755.x.

Lefcourt, A. 1982. Effect of teat stimulation on sympathetic tone in bovine mammary gland. J. Dairy Sci. 65:2317-2322. https://doi .org/10.3168/jds.S0022-0302(82)82503-4.

Maltz, E., D. J. Reinemann, and M. A. Davis. 2000. Blood flow and oxygen concentration of teat-end tissue before and after machine milking. Pages 2-12 in Proc. 2000 ASAE Annual International Meeting, Milwaukee, WI. Am. Soc. Agric. Eng., St. Joseph, MI.

Mattoon, J. S., and T. G. Nyland. 2015. Fundamentals of diagnostic ultrasound. Pages 1-49 in Small Animal Diagnostic Ultrasound. 3rd ed. J. S. Mattoon and T. G. Nyland, ed. Elsevier, St. Louis, MO.

Mein, G. A., F. Neijenhuis, W. F. Morgan, D. J. Reinemann, J. E. Hillerton, J. R. Baines, I. Ohnstad, M. D. Rasmussen, L. Timms, J. S. Britt, R. Farnsworth, N. Cook, and T. Hemling. 2001. Evaluation of bovine teat condition in commercial dairy herds: 1 . Noninfectious factors. Pages 347-351 in Proc. 2nd Int. Symp. Mastitis and Milk Quality, Vancouver, BC, Canada. Natl. Mastitis Counc. Inc., Madison, WI. 
Melvin, J. M., W. Heuwieser, P. D. Virkler, D. V. Nydam, and M. Wieland. 2019. Machine milking-induced changes in teat canal dimensions as assessed by ultrasonography. J. Dairy Sci. 102:26572669. https://doi.org/10.3168/jds.2018-14968.

Müller, H., M. Heinrich, N. Mielenz, S. Reese, A. Steiner, and A. Starke. 2017. Evaluation of arterial digital blood flow using Doppler ultrasonography in healthy dairy cows. BMC Vet. Res. 13:162. https://doi.org/10.1186/s12917-017-1090-8.

Neijenhuis, F., H. W. Barkema, H. Hogeveen, and J. P. Noordhuizen. 2000. Classification and longitudinal examination of callused teat ends in dairy cows. J. Dairy Sci. 83:2795-2804. https://doi.org/10 .3168/jds.S0022-0302(00)75177-0.

Neijenhuis, F., G. H. Klungel, and H. Hogeveen. 2001b. Recovery of cow teats after milking as determined by ultrasonographic scanning. J. Dairy Sci. 84:2599-2606. https://doi.org/10.3168/jds .S0022-0302(01)74714-5.

Neijenhuis, F., G. A. Mein, J. S. Britt, D. J. Reinemann, J. E. Hillerton, R. Farnsworth, J. R. Baines, T. Hemling, I. Ohnstad, N. Cook, and W. F. Morgan. 2001a. Evaluation of bovine teat condition in commercial dairy herds: 4 . Relationship between teat-end callosity or hyperkeratosis and mastitis. Pages 3362-3366 in Proc. 2nd Int. Symp. Mastitis and Milk Quality, Vancouver, BC, Canada. Natl. Mastitis Counc. Inc., Madison, WI.

Nickerson, S. C., and J. W. Pankey. 1983. Cytologic observations of the bovine teat end. Am. J. Vet. Res. 44:1433-1441.

NMC (National Mastitis Council). 2012. Procedures for Evaluating Vacuum Levels and Air Flow in Milking Systems. National Mastitis Council, Verona, WI.

NRC (National Research Council). 2001. Nutrient Requirements of Dairy Cattle. 7th rev. ed. Natl. Acad. Press, Washington, DC.

Odorčić, M., M. D. Rasmussen, C. O. Paulrud, and R. M. Bruckmaier. 2019. Review: Milking machine settings, teat condition and milking efficiency in dairy cows. Animal 13(S1):s94-s99. https://doi .org/10.1017/S1751731119000417.

Ordolff, D. 2000. Oberflächentemperaturen an Euter und Zitze bei konventionellen und automatischen Melkverfahren. Kieler Milchwirtsch. Forschungs. 52:5-10.

Paulrud, C. O. 2005. Basic concepts of the bovine teat canal. Vet. Res. Commun. 29:215-245. https://doi.org/10.1023/B:VERC .0000047496 .47571 .41 .

Paulrud, C. O., S. Clausen, P. E. Andersen, and M. D. Rasmussen. 2005. Infrared thermography and ultrasonography to indirectly monitor the influence of liner type and overmilking on teat tissue recovery. Acta Vet. Scand. 46:137-147. https://doi.org/10.1186/ 1751-0147-46-137.

Penry, J. F., J. Upton, G. A. Mein, M. D. Rasmussen, I. Ohnstad, P. D. Thompson, and D. J. Reinemann. 2017. Estimating teat canal cross-sectional area to determine the effects of teat-end and mouthpiece chamber vacuum on teat congestion. J. Dairy Sci. 100:821-827. https://doi.org/10.3168/jds.2016-11533.

Persson, K. 1991. Microcirculation in the bovine teat skin, measured by laser Doppler flowmetry. Acta Vet. Scand. 32:131-133.

Pinaffi, F. L. V., E. R. Araujo, L. A. Silva, and O. J. Ginther. 2017. Color-Doppler signals of blood flow in the corpus luteum and vascular perfusion index for ovarian and uterine arteries during expansion of the allantochorion in Bos taurus heifers. Theriogenology 102:35-43. https://doi.org/10.1016/j.theriogenology.2017.07.008.

Scholbach, T. M., J. Konje, and B. Huppertz. 2012. Pixelwise quantification of placental perfusion visualized by 3D power Doppler sonography. Ultraschall Med. 33:E88-E94. https://doi.org/10.1055/ s-0031-1299483.

Siqueira, L. G., E. K. Arashiro, A. M. Ghetti, E. D. Souza, L. F. Feres, L. F. Pfeifer, J. F. Fonseca, and J. H. Viana. 2019. Vascular and morphological features of the corpus luteum 12 to 20 days after timed artificial insemination in dairy cattle. J. Dairy Sci. 102:5612-5622. https://doi.org/10.3168/jds.2018-15853.

Starke, A., S. Schmidt, A. Haudum, T. Scholbach, P. Wohlsein, M. Beyerbach, and J. Rehage. 2011. Evaluation of portal blood flow using transcutaneous and intraoperative Doppler ultrasonography in dairy cows with fatty liver. J. Dairy Sci. 94:2964-2971. https:// doi.org/10.3168/jds.2011-4156.

Tangorra, F. M., V. Redaelli, F. Luzi, and M. Zaninelli. 2019. The use of infrared thermography for the monitoring of udder teat stress caused by milking machines. Animals (Basel) 9:384. https://doi .org/10.3390/ani9060384.

Upton, J., J. F. Penry, M. D. Rasmussen, P. D. Thompson, and D. J. Reinemann. 2016. Effect of pulsation rest phase duration on teat end congestion. J. Dairy Sci. 99:3958-3965. https://doi.org/ $10.3168 /$ jds. $2015-10466$.

Urbaniak, G. C. and S. Plous. 2013. Research randomizer. Accessed Apr. 3, 2020. https://www.randomizer.org/.

Wieland, M., J. M. Melvin, D. V. Nydam, and P. D. Virkler. 2019b. A longitudinal prospective cohort study investigating the association of pre-milking stimulation and teat-end shape on milking characteristics and teat tissue condition in dairy cows. BMC Vet. Res. 15:58. https://doi.org/10.1186/s12917-019-1803-2.

Wieland, M., D. V. Nydam, N. Älveby, P. Wood, and P. D. Virkler. 2018. Short communication: Teat-end shape and udder-level milking characteristics and their associations with machine milkinginduced changes in teat tissue condition. J. Dairy Sci. 101:1144711454. https://doi.org/10.3168/jds.2018-15057.

Wieland, M., D. V. Nydam, and P. D. Virkler. 2017. A longitudinal field study investigating the association between teat-end shape and two minute milk yield, milking unit-on time, and time in low flow rate. Livest. Sci. 205:88-97. https://doi.org/10.1016/j.livsci .2017.09.011.

Wieland, M., T. M. Scholbach, S. Shirky, P. D. Virkler, D. V. Nydam, S. H. Cheong, and I. R. Porter. 2019c. Technical note: Development and evaluation of a standardized technique to assess blood perfusion in teats of dairy cows using power Doppler ultrasonography. J. Dairy Sci. 102:9488-9494. https://doi.org/10.3168/jds.2019 -16670 .

Wieland, M., P. D. Virkler, A. H. Borkowski, N. Älveby, P. Wood, and D. V. Nydam. 2019a. An observational study investigating the association of ultrasonographically assessed machine milking-induced changes in teat condition and teat-end shape in dairy cows. Animal 13:341-348. https://doi.org/10.1017/S1751731118001246.

Zwertvaegher, I., S. De Vliegher, B. Verbist, A. Van Nuffel, J. Baert, and S. Van Weyenberg. 2013. Short communication: Associations between teat dimensions and milking-induced changes in teat dimensions and quarter milk somatic cell counts in dairy cows. J. Dairy Sci. 96:1075-1080. https://doi.org/10.3168/jds.2012-5636.

\section{ORCIDS}

M. Wieland $\odot$ https://orcid.org/0000-0003-0513-1782 A. Sipka (ㄴ https://orcid.org/0000-0002-8646-824X

P. D. Virkler @ https://orcid.org/0000-0002-9177-4663

D. V. Nydam @ 1 https://orcid.org/0000-0001-7717-4859

N. Älveby @ https://orcid.org/0000-0003-3678-1331

I. R. Porter (i) https://orcid.org/0000-0002-5501-4683 